\title{
Brand Extension Of Fast Moving Consumer Goods To Customers' Perception
}

\author{
Budiono Hardjono \\ budiono@utem.edu.my \\ Tan Bee Ying \\ Universiti Teknikal Malaysia Melaka
}

\begin{abstract}
The cost of launching a totally new product or brand is usually very high accompanied by the risk of failure in an overcrowded market. Therefore, brand extension strategy is used due to its built in advantages. This research examined in depth, the factors in a brand extension which influence to customer perception about the existing brand in fast moving consumer goods (FMCG) sector. Four variables such as brand fit, perceived quality, brand familiarity and customer innovativeness, were used to establish the relationship with the customers 'perception. A questionnaire was developed and distributed to 200 respondents from hypermarket FMCG products' consumers in Melaka city. It was found that in the context of personal hygiene products, only brand fit and perceived quality have a strong influence on the customer perception. Marketer should, however, carefully to evaluate their extension especially for local brand since not all factors in this extension significantly influence the customer perception.
\end{abstract}

Keywords: brand extension, customer perception, fast moving consumer goods

\section{INTRODUCTION}

People nowadays are surrounded by all kinds of brands and brand extensions are introduced by companies to expand their brand to the market. A greater starting point for a brand to be successful depends on the customers' awareness and consciousness on the brand itself. Due to the intense competition in the market, almost every industry shows the fact that a rise in number of products become similar to the competitors' ones (Blomquist and Holm, 2004). Therefore with the perception of customers on the brand, companies can then take brand extension as one of their marketing strategy to differentiate their products from the others and at the same time try to acquire more market shares.

A brand extension occurs when a firm extends an existing brand name to launch another product in a different category (Keller, 2013). Using Ansoff's Growth Matrix as a useful perspective to understand brand extension, the growth strategies can be categorized according to whether they rely on existing or new products and market. Aaker and Keller's (1990) model of consumer brand extension attitude formation has triggered additional brand extension research in various countries.

Brand extension strategy was an extremely important decision for a company. This is because the incorrect decision on the extension could bring a brand dilution which may be costly to alter the affected image of the brand (Soomro et al. 2013). In order to be familiar with the factors that most affected the success ability of brand extension, marketers should know the phenomena regarding which factors that consumers consider when choosing the product and how the factors affect the consideration that leads to positive and favourable perception towards the extension.

In this context, this study is positioned more specifically in fast moving consumer goods (FMCG) sector. FMCG constitutes a large part of consumers' budget in all countries (Çelen et al., 2005) and Malaysia is no exception. FMCG sector is defined as relatively inexpensive, frequently purchased and rapidly consumed items on which customers exert only minimal purchasing effort (Leahy, 2011). According to Leahy (2011), the customers' perspective relationship does not exist in FMCG markets and that the nature of exchange in such markets is not relationship based. This research conducted to determine the influence of brand extension on customer perception and will indirectly find out whether the variables can affect the customer perceive in FMCG sector.

New product launch is always good for business growth. However, the rates of new product failure have tremendously increased over the last few decades. 
Therefore, companies always launch a new product using brand extension strategy. This is because, with brand extension, customers will easily accept a new product, the promotion cost is lower and there are comparatively fewer chances to face failures if it is compared to launching a totally new product. According to Taylor (2006), most companies use brand extension strategy because of its lower cost and it is a less risky way of launching innovation than creating a new brand.

In fast moving consumer goods (FMCG) segment, the companies are also applying brand extension strategy because of the inbuilt advantages. The study done by Nielsen, a market research firm in United States, showed that there were five times more successful to extend existing FMCG brands than launching a new brand in India (Beura, 2016). In Malaysia, the consumer purchasing power in FMCG sector gained the traction in the first quarter of 2016 and most of the categories, include household, registered a healthier growth. From this, it can be seen that there stands a far better opportunity of growing in Malaysia's FMCG sector. However, the influences of brand extension on consumer consciousness studied in the FMCG industry has not been tested in Malaysia especially in Melaka's context.

With the rapid development of FMCG sector, more and more FMCG brands extensions have appeared in the market. These brand extensions tend to be followed by other companies to keep their positions in the market competition. Although extending the brand will enhance, revitalize the image of the parent brand and give more choices to the customers, at a certain point it can be confusing, frustrating and even cannibalize the sales of the parent brand. (Keller, 2013). Therefore marketer should understand how to extend the brand in the proper way.

The good customer perception about branding is so important to win the competition in FMCG market, but by understanding on what determinant factors that have a positive relationship to this perception, it can lead the marketers to achieve this objective. This study focused on investigating these factors and its relationship to the customer perception.

Referring to some previous research, there are several important factors associated to the issue of brand extension. These factors are brand fit, perceive quality, brand familiarity, and customer attitude. The focus of the questions in this research is whether all of the above factors have an influence on the customer's perception of an existing brand and how the model of their relationship. To find out the answers to the above questions, some research objectives are set up as followed: (1) To investigate the influence of brand fit on brand customer perception, (2) To examine the influence of perceiving quality on brand customer perception, (3) To determine the influence of brand familiarity on brand customer perception, (4) To evaluate the influence of customer attitude on brand customer perception, (5) To develop the relationship between brand fit, perceive quality, brand familiarity and customer attitude toward brand customer perception.

Nowadays a brand is a valuable asset and branding means the creation of the asset. (Vazifehdoost 2016). American Marketing Association (AMA) defines a brand as a name, term, sign, symbol, or design, or a combination of these elements, intended to identify the goods and services of one seller or group of sellers and to differentiate them from those of competitors. A marketer has created a brand whenever he or she creates a new name, logo, or symbol for a new product (Keller, 2013).

Companies always use different methods to extend their business to various market and different segments. Regarding different market strategies, brand extension is one of the most popular methods in order to grow and expand their business. This is because brand extension can easily enter a new market due to its existing good image and equity of the brand. According to Aaker and Keller (1990), the leverage of a strong brand name can substantially reduce the risk of launching a product into a new market because of its familiarity and knowledge of an existing brand are provided to consumers. A good image and status of the parents brand in the market enable the extension to start a good growth in the respective market.

There are many definitions for brand extension. Referring to Khan and Janthimapornkij (2011), brand extension is defined as any effort to extend established brand names to launch new or modified products or lines. Keller and Aaker (1992) defines brand extension as the use of established brand names to enter new product categories or classes.

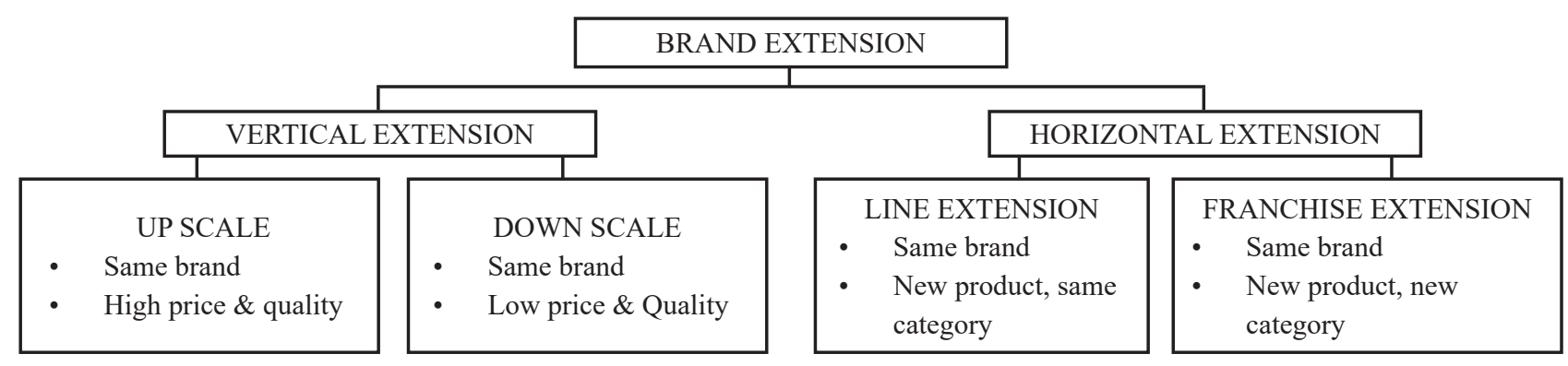

Figure 1: Brand Extension Model 
Adapted from Kim et al (2001); Martínez \& Pina (2003); Henry Xie (2008); Bosinakis \& Johansson (2009); Khan \& Janthimapornkij (2011).

There are two types brand extension, vertical and horizontal. The application of an existing brand name for extending a new product either in the same product class or in a totally new product category from the parent brand is considered as a horizontal brand extension. According to Aaker and Keller (1990), a horizontal brand extension can be further divided into two categories. There are line extension and franchise extension. The focus on these brand categories was usually diverse (Soomro et al., 2013). An existing brand name and same product class used for entering a new marketing segment are associated to line extension, while franchise extension, whereby a current brand name is used for entering a different product category.

Meanwhile, a vertical brand extension refers to introduce a similar brand to the same category but usually with a different price and quality point (Keller and Aaker, 1992; Chen and Gu, 2012). There are two directions for vertical extension. A new product which was priced higher and with higher quality level will be called as upscaling. In contrast, the new product with lower price and quality will be termed as down scaling.

Brand fit means that how the extended brand resembles with parent brand in terms of quality and features. According to Arslan and Altuna (2010), the brand fit is how closely related or similar an extension is with the parent brand. It is not only limited to the same product category but also other product classes. Customers evaluate brand extension fit by judging the similarities between the extension and the parent brand and also the steadiness of the brand concept (Arslan and Altuna, 2010). The fit between extended brand and parent brand is identified as one of the major determinants of success brand extension (Volckner et al., 2010).

Brand fit may exist in customer mind because of his or her association that is made about the brand. Product associations may be based on product category, product attribute, application, technology, channel, user and brand personality (Aaker, 2004). The strength of a brand is highly dependent on the customers' associations when the customers come across the brand name and the attachment with parent brand. Customers will have positive attitudes when there are strong associations for a brand.

Strengthening the brand fit between parent brand and extended brand bring positive impact on customer perception towards the brand (Aaker and Keller, 1990; Park et al., 1991; Völckner and Sattler, 2006). Buil et al (2009) also have the result that brand extensions with high brand fit will have more favourable customers' evaluations and at the same time reduce the negative feedback effects of extensions on parent brand equity. A brand extension is easily accepted by customers when it is introduced to the market when the fit between the parent brand and the extension of the brand is high regarding product category (Aaker and Keller, 1990; Park et al., 1991) or associations (Park et al., 1991).

When a brand extension is introduced to the market, it is easily accepted by consumers especially if there is a high fit between the extension and the parent brand regarding product category (Aaker and Keller, 1990; Park et al., 1991) or associations (Park et al., 1991; Broniarczyk and Alba, 1994).

Perceived quality refers to the customer's awareness of products' superior quality in relation to other products (Aaker, 2009). Perceived quality is a consumer judgment on the accumulative product benefits and a subjective feeling of product quality. It can show the salient differentiation of a product or a service and become a selective brand in customers' mind (Chi et al., 2009). On the other hand, Dens \& Pelsmacker (2015) states that the perceived brand quality refers to customers' assessments and judgments of the excellence of a product.

Perceived quality cannot be objectively determined because it is a perception not simply satisfaction (Chen and $\mathrm{Gu}, 2012$ ). It differs from actual quality. The customer perception of quality can be affected by earlier impressions. The perceived product quality of a particular brand might depend on past experiences from the practical use or possible feedbacks from others. According to Khan and Janthimapornkij (2011), perceived quality will be affected by factors such as previous experience, education level, and perceived risk and situational variables such as purchase purpose, purchase situation, time pressure, and social background from consumers. A previous bad image of a product will affect customers' judgment on product quality in the future. If a customer goes to a purchase trial but the product does not meet his or her expectation, he or she will not continue to purchase the product. Therefore, the customer quality perception should be positive for a continuous purchase of a product (Khan and Janthimapornkij, 2011). Moreover, even though the product quality has been changed, consumers will not trust that product because of their unpleasant experience in previous (Aaker, 1996).

Quality of an extended brand is an important aspect from customer point of view when he or she perceives about the brand. Sometimes it is more difficult to determine a customer's evaluation of a brand quality according to his or her perception than deliver the actual quality. The results of the second study by Aaker and Keller (1990) stated that satisfied customers always have a strong attitude on the quality of both parent 
and extended brand. In simple words, if customers are satisfied with the perceived quality of parent brand, the customers' acceptability of the brand extension will increase. A brand extension strategy is founded on the assumption that beliefs or attitudes about the original brand will transfer to the extension (Martinez et al., 2008). The perceived brand quality is expected to influence consumers' attitudes towards the extensions. Favourable perceptions of a high-quality brand should spill over as positive impressions of an extension (Aaker and Keller, 1990). Aaker (2009) also argues that a strong brand with respect to perceived quality will be able to extend further, and will find a higher success probability than a weaker brand. High quality brands are usually well established because of their elaborate, strong and positive network of associations in customers' memories.

Brand familiarity can be considered as the number of product related experiences that have been accumulated by the consumer through product usage, advertising and others (Keller (1993). Any type of experience with and exposure to the brand increases familiarity (Arslan and Altuna, 2010). Brand familiarity can be understood as customers' direct and indirect experience with the brand and with its entire product portfolio (Campbell and Keller, 2003). Customer tends to purchase a brand which he or she usually use or had experience of that product. How well the customers recognize the product depends on their familiarity with the brand. From the study conducted by Coates et al. (2006), the experiment showed that priming for a familiar brand name can extend beyond the stage of consideration, to influence customers' preferred choices. It was found that existed brand name was significantly more likely to be selected in the first place than the new brand.

The brand with a high level of brand familiarity will be easily remembered and aware once the customers want to buy a product. Customers draw on familiarity to guide their choice and reducing perceived risk. A product with high brand familiarity will receive higher customer preferences because it has higher market share and quality evaluation. Brand awareness can help customers to recognize a brand from a product category and make a purchase decision. According to Chi et al (2009), brand awareness has a great influence on selections and can be a prior consideration base in a product category. It is also acts as a critical factor in the consumer purchase intention which certain brands will accumulate in customers' mind to affect their purchase decision. The brand with the high awareness will have the high familiarity of the brand.

Customer overall judgment of the brand is called customer attitude or innovativeness. Customer innovativeness means the relative willingness of a customer to try a new product or service. It is the degree of how fast a customer is to adopt an innovation or brand extension than other customers. Beura (2016) defines the innovativeness as a personality trait which there is a rise on an individual's receptivity to new ideas and willingness to try new practices and brands. The idea is that the customers who are more innovative can accept the brand extensions easier. This is because these kinds of customers are more adventurous and less dependent on perceptions of perceived fit between the extended brand and the parent brand (Czellar, 2003). According to Henry Xie (2008), many researchers define customer innovativeness as a level of adopting an innovation early and a degree of how individuals are receptive to the latest innovations.

Customer attitude towards any brand can be judged by many ways. For instance, how frequent the customers buy the product, the consumer loyalty on a brand and others. When there is a negative attitude towards the brand, the brand is said to fail. The negative attitude leads the customer to avoid certain brand (Keller, 1993). It is important to improve the innovativeness of a customer on the brand extension because this brings a positive effect on the brand image (Keller, 1993). Therefore, attitude towards the extension is an important variable in determining whether the extension is accepted by the consumer or not. If the attitude towards the extension is high, this will have a positive effect on the product brand image, if it is low, there will be a negative or negligent effect on product brand image. Therefore, it could be easily said that the success of a marketing program depends on creating favourable brand associations (Keller, 1993) and these positive attitudes have a positive impact on product brand image.

On the other hand, Martínez and Pina (2010) stated that innovativeness is a concept that represents the customers' propensity to buy new products and consider new ideas. Meanwhile, some studies show a positive impact of customers' innovativeness on brand extension evaluations for both FMCG products (Völckner and Sattler, 2006) and services (Hem et al., 2003). Highly-innovative individuals find far extensions appealing (Henry Xie, 2008) and do not mind to try products that differ from the parent brand. Therefore, the companies that are stretching their brands should target the customers that have a high level of innovativeness.

Nowadays, due to the fast development of every industry to fulfil customers' needs and wants, choices for customers increase and, moreover, a high competition among the producers and service providers has created. This has resulted in a sensitivity of product selection 
among customers. Most of the customers now are well informed, much conscious about the market situation and can easily compare the products in terms of price, performance or quality which influence their purchase choice. In this situation, a strong relationship between brands and customers is important in order to create a positive customer perception. Perception plays an important role in creating strong customer loyalty towards a brand. There are different factors that can influence the perception of the customer such as satisfaction, experience, promises of the company, offering of competitors and others. Customer perception also change depends on the circumstances that lead to different needs and preferences. A company should know how to increase the perception of customers by using various strategies to create awareness, trust, and satisfaction on customers which lead to high perceived value and strong customer relationship.

Furthermore, customer perception will be uncertain at the beginning of a relationship with a brand. It will change to be positive or negative as time passes due to the circumstances (Khan and Janthimapornkij, 2011). This is because different circumstances such as a change in external environment, offering of competitors, previous experiences, public opinions and others, can lead to different needs and preferences. Companies use different strategies to improve the perception of the customer through various channels of communication. These communication channels create awareness in consumers. Trust also plays an important role in customer perception. Companies should know the points due to which they can increase the customer satisfaction and trust, which lead to high perceived value and strong customer relationship.

\section{METHOD}

This study used a quantitative methodology while it was designed by using explanatory research since most of the discussion on findings were based on established and well-known theory. Research is focused to examine the relationship between variables in brand extension (brand fit, perceived quality, brand familiarity, and customer attitude) towards customer brand perception. Based on that, the regression model between them was developed.

The questionnaire was used as a research instrument which variables to be questioned were set up based on four-factor dimensions in brand extension and its customer brand perception as the dependent variable. These variables and dimension are as seen in Table 1.
Table 1. Details of the Measurements of the factors of Brand Extension

\begin{tabular}{|c|c|}
\hline $\begin{array}{c}\text { Independent } \\
\text { Variables }\end{array}$ & Dimension \\
\hline \multirow{6}{*}{$\begin{array}{l}\text { Brand Fit } \\
\text { The factor } \\
\text { indicates } \\
\text { whether there is } \\
\text { conceptually fit } \\
\text { between parent } \\
\text { brand and extended } \\
\text { brand }\end{array}$} & Category relationship \\
\hline & $\begin{array}{l}\text { The relationship between the category of } \\
\text { the product under the same brand }\end{array}$ \\
\hline & Image to the parent brand \\
\hline & The reputation of the parent brand \\
\hline & Adaptability \\
\hline & $\begin{array}{l}\text { The brand extension is flexible and } \\
\text { updatable }\end{array}$ \\
\hline \multirow{3}{*}{$\begin{array}{l}\text { Perceived Quality } \\
\text { The quality of } \\
\text { product that } \\
\text { customer take into } \\
\text { consideration }\end{array}$} & \\
\hline & $\begin{array}{l}\text { The feature of the product that brings } \\
\text { benefits to the users }\end{array}$ \\
\hline & $\begin{array}{l}\text { Appearance } \\
\text { package, character, content, fragrance }\end{array}$ \\
\hline \multirow{6}{*}{$\begin{array}{l}\text { Brand Familiarity } \\
\text { Consumer } \\
\text { recognition and } \\
\text { acquaintance of the } \\
\text { brand }\end{array}$} & Popularity \\
\hline & $\begin{array}{l}\text { The popularization of the brand among } \\
\text { the people }\end{array}$ \\
\hline & Awareness \\
\hline & $\begin{array}{l}\text { The customer ability to confirm prior } \\
\text { exposure to the brand and retrieve the } \\
\text { brand from memory }\end{array}$ \\
\hline & Memorable \\
\hline & $\begin{array}{l}\text { The brand is inherently memorable and } \\
\text { getting the attention of the customers }\end{array}$ \\
\hline \multirow{6}{*}{$\begin{array}{l}\text { Customer Attitude } \\
\text { (Innovativeness) } \\
\text { Customers overall } \\
\text { judgment of the } \\
\text { brand. Customer } \\
\text { attitude towards the } \\
\text { brand extension }\end{array}$} & Acceptability \\
\hline & $\begin{array}{l}\text { The customer accept and adapt the } \\
\text { extended brand }\end{array}$ \\
\hline & Attractiveness \\
\hline & The brand attraction towards the customer \\
\hline & Uniqueness \\
\hline & The specialty of the brand \\
\hline
\end{tabular}

Non-probability purposive sampling technique was conducted for this study based on the experience from previous research that target respondents were easy to be found out as customers of household FMCG products around the hypermarkets in the big city. Melaka city was chosen since it is a quite big city and can be considered as a representative model for the city that has big customers of household FMCG products. Among 300 questionnaires distributed, about 200 completed questionnaires can be collected and analysed. Likert scale with the range 1-5 was applied in the questionnaire in order to respondents can make assessment for every question they answered. 
Table 2: Data Demographic of Respondents

\begin{tabular}{|c|c|c|}
\hline Gender & Frequency & Percentage \\
\hline Male & 69 & 34.5 \\
\hline Female & 131 & 65.5 \\
\hline Total & 200 & \\
\hline \multicolumn{3}{|l|}{ Age } \\
\hline 25 years old and below & 73 & 36.5 \\
\hline $26-40$ years old & 65 & 32.5 \\
\hline $41-60$ years old & 49 & 24.5 \\
\hline 61 years old and above & 13 & 6.5 \\
\hline \multicolumn{3}{|l|}{ Race } \\
\hline Malaysia & 83 & 41.5 \\
\hline Chinese & 94 & 47.0 \\
\hline Indian & 20 & 10.0 \\
\hline Others & 3 & 1.5 \\
\hline \multicolumn{3}{|l|}{ Educational Level } \\
\hline High School Degree or below & 3 & 1.5 \\
\hline SPM/STPM & 58 & 29.0 \\
\hline Diploma/Bachelor's Degree & 123 & 61.5 \\
\hline Master's Degree/Doctorate's Degree & 16 & 8.0 \\
\hline \multicolumn{3}{|l|}{ Employment Status } \\
\hline $\begin{array}{l}\text { Unemployed (e.g. housewife, } \\
\text { retirees) }\end{array}$ & 28 & 14.0 \\
\hline Student & 57 & 28.5 \\
\hline Employee & 79 & 39.5 \\
\hline Self-Employed/Professional & 32 & 16.0 \\
\hline Manager/Director & 4 & 2 \\
\hline \multicolumn{3}{|l|}{ Monthly Income } \\
\hline RM1000 and below & 78 & 39.0 \\
\hline RM1001-RM3000 & 67 & 33.5 \\
\hline RM3001-RM6000 & 37 & 18.5 \\
\hline RM6001 and above & 18 & 9 \\
\hline \multicolumn{3}{|l|}{$\begin{array}{l}\text { Monthly Spending for Personal } \\
\text { Hygiene FMCGs }\end{array}$} \\
\hline RM100 and below & 67 & 33.5 \\
\hline RM101-RM300 & 77 & 38.5 \\
\hline RM301-RM500 & 32 & 16 \\
\hline RM501 and above & 24 & 12 \\
\hline \multicolumn{3}{|l|}{ Preferred Brand } \\
\hline Dettol & 69 & 34.5 \\
\hline Lifebuoy & 43 & 21.5 \\
\hline Antabax & 15 & 7.5 \\
\hline Colgate-Palmolive & 21 & 10.5 \\
\hline Lux & 14 & 7.0 \\
\hline Others & 38 & 19.0 \\
\hline
\end{tabular}

There were four variables that predicted to have influence toward customer brand perception. These variables were set up as independent variables which consist of elements of brand extension such as brand fit, d quality, brand familiarity, and customer attitude. These variables referred to the theory from Aaker and Keller, (1990); Park et al., (1991); Völckner and Sattler, (2006), and Buil et al (2009). By adopting this, theoretical framework and hypothesis of this research can be constructed as seen in the Figure 2.

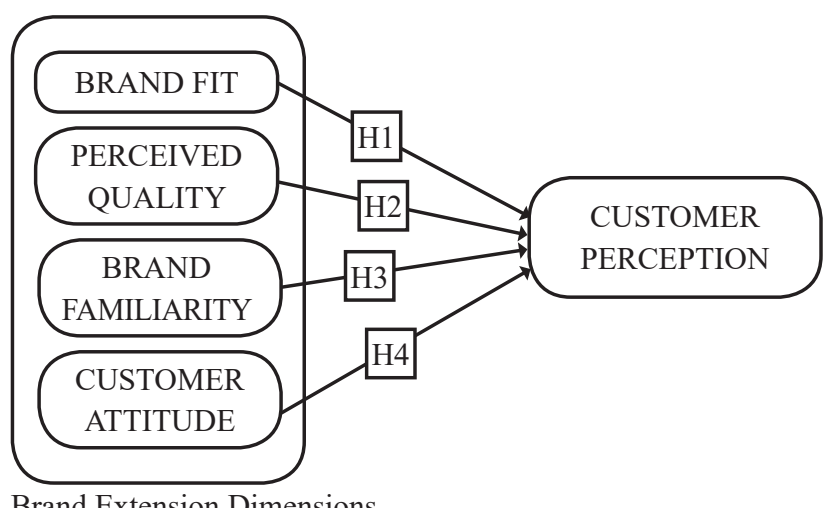

Figure 2. Theoretical Framework

H1: Brand fit of personal hygiene FMCGs have positive relationship with customer brand perception

$\mathrm{H} 2$ : Perceive quality of personal hygiene FMCGs have positive relationship with customer brand perception

H3: Brand familiarity of personal hygiene FMCGs have positive relationship with customer brand Perception

H4: Customer innovativeness on personal hygiene FMCGs have positive relationship with customer brand perception

\section{RESULTS}

From the questionnaires answered by respondents, the summary of the demographic profile is as shown in Table 2. Respondents are dominated by Malaysian and Chinese females with SPM/STPM and Diploma/ Bachelor degree education level. In term of economic power, most of them are medium low to medium up income level who are dominant in spending about RM 100 - RM 300 per month for personal hygiene FMCGs.

The result from cross tabulation of education level versus brand preference indicated that there was a tendency that dominant respondents will choose similar preference brands. Even the tendency was also similar 
when income level was cross tabulated with brand preference. This shows that brand preference is important for customers regardless of education level or income. All of these results can be seen in Figure 3 and 4.

By using the Likert scales with the range from 1 to 7, most of the respondents considered agreeing with the statements that asked to them. The score for all of the answers on the dimension of brand extension is more than 5.0 which is above their median (neutral) value. This means that most of the respondents value more than 5.0, it indicated that most of the respondents slightly agree with the statements on the brand extension dimensions. All results for these brand extension dimensions can be seen in the Table 3 .

Pearson correlation analysis can be described more clearly on how strong or weak the correlation between all of the predictors and its dependent variables as shown in Table 4.as result from SPSS calculation.

All Pearson coefficients of the predictors are positive and significant at 0.01 (2 tails), means that these predictors have a positive correlation with their dependent variable with the level of confidence more than $95 \%$, the number that usually used as a standard for doing the research. However, the strength of each predictor differs for each. Started from the stronger one, the relationship of predictors to dependent variables respectively are brand fit (0.628), perceived quality (0.518), Customer innovativeness (0.470), and brand familiarity (0.3670. Based on Saunders at al. (2012), Pearson coefficient of 0.35 to 0.59 is considered as moderate positive relationship while 0.60 to 0.79 are considered as a strong positive relationship.

Correlation analysis just indicates that there is a relationship between independent and dependent variables, but it cannot describe what kind of relationship it is. Therefore, to understand this relationship, regression analysis needs to be done. Table 5 to Table 7 shows the results of multi linear regression analysis calculated by SPSS software.

Table 5. Model Summary

\begin{tabular}{ccccc}
\hline Model & $\mathrm{R}$ & $\begin{array}{c}\mathrm{R} \\
\text { Square }\end{array}$ & $\begin{array}{c}\text { Adjusted R } \\
\text { Square }\end{array}$ & $\begin{array}{l}\text { Std. Error of } \\
\text { the Estimate }\end{array}$ \\
\hline 1 & $.676^{\mathrm{a}}$ & .458 & .447 & .63416
\end{tabular}

a. Predictors: (Constant), CUSTINNO, BRDFIT, BRDFAM, PERCQUA

The $\mathrm{R}$ square value of 0.458 represents how much of the total variation in the dependent variable (customer perception) can be explained by the independent variables (brand fit, perceived quality, brand familiarity and innovativeness).

In Table 6, degree of freedom is defined and it can be used to check the hypothesis by using statistical t-test later on.
Table 6. ANOVA ${ }^{\mathrm{a}}$

\begin{tabular}{rrrrrrr}
\hline \multirow{2}{*}{ Model } & & $\begin{array}{c}\text { Sum of } \\
\text { Squares }\end{array}$ & Df & $\begin{array}{c}\text { Mean } \\
\text { Square }\end{array}$ & F & Sig. \\
& & & & & \\
\hline & Regression & 66.170 & 4 & 16.543 & 41.135 & $.000^{\mathrm{b}}$ \\
Residual & 78.421 & 195 & .402 & & \\
Total & 144.591 & 199 & & & \\
\hline
\end{tabular}

a. Dependent Variable: CUSTPERC

b. Predictors: (Constant), CUSTINNO, BRDFIT, BRDFAM, PERCQUA

Table 7. Coefficients ${ }^{\mathrm{a}}$

\begin{tabular}{ccccccc}
\hline & \multicolumn{2}{l}{$\begin{array}{l}\text { Unstandardized } \\
\text { Coefficients }\end{array}$} & \multicolumn{2}{l}{$\begin{array}{l}\text { Standardized } \\
\text { Coefficients }\end{array}$} & & Sig. \\
\cline { 2 - 5 } Model & $\mathrm{B}$ & $\begin{array}{l}\text { Std. } \\
\text { Error }\end{array}$ & Beta & & \\
\hline (Constant) & 2.277 & .320 & & 7.110 & .000 \\
BRDFIT & .380 & .054 & .465 & 7.076 & .000 \\
PERCQUA & .200 & .063 & .217 & 3.200 & .002 \\
BRDFAM & -.024 & .059 & -.027 & -.402 & .688 \\
CUSTINNO & .113 & .061 & .134 & 1.832 & .068 \\
\hline
\end{tabular}

a. Dependent Variable: CUSTPERC

The relationship model between independent and dependent variables can be developed by inserting all of the regression coefficients of independent variables and constant (Table 7) into a simple linear function so that the model can be expressed as:

Customer's Perception $=2.277+(0.38$ Brand Fit $)+$ (0.20 Perceive Quality) - (0.024 Brand Familiarity $)+$

0.113 Customer Innovativeness)

Equation (1) needs to be checked whether all of the independent variables are valid or not. In another word, all hypothesis that has been developed in the beginning of this research can be accepted or not. For this purpose, t-test statistical was used. By inserting data of degree of freedom (df) from Table 6, t-calculated values from Table 7 and $95 \%$ confident interval, t-table can be determined. When $\mathrm{t}$-calculated is greater than t-table, hypothesis is accepted, on the opposite, hypothesis is rejected. The result on the hypothesis test can be shown in Table 8.

Because $\mathrm{H} 3$ and $\mathrm{H} 4$ were rejected, brand familiarity and customer innovativeness are no longer valid as predictor to the regression equation (1), therefore this equation should be corrected as seen in Equation (2) below.

Customer's Perception $=2.277+(0.38$ Brand Fit $)+$ (0.20 Perceive Quality)

Not similar to what previous researchers stated (Matarid et al. 2014; Soomro et al. 2013; Klink \& Smith 
2001), this research indicate that both brand familiarity and customer innovativeness do not have positive relationship to the customer perception. Respondents slightly don't care about these two dimensions as shown as well in Table 13. The score they gave tend to be in neutral value and lower compared to the other dimensions. As long as the extended brand are related to the parent brand, they perceived that it will have a good quality and at the end will influence the perception.

\section{DISCUSSION}

Although brand familiarity and brand attitude (customer innovativeness) are important components to introduce a new extension of a brand, in this research they did not have the significant implication toward the perception of consumers. All of these can be indicated by the low alpha Pearson values they have and the rejection of $\mathrm{H} 3$ and $\mathrm{H} 4$ during the hypothesis test.

Most of the respondents were familiar with the parent brand but when they were asked about the extension of this parent brand for the other category, they did not consider this new category as good as the category of the parent brand they usually used. The customers also cannot be convinced to directly try to use this new category of product since they were not sure about the expertise of brand owner to this new extension. Every time there was a new extension category of the parent brand, customers tend to think first, wait, and see whether the brand owner has the expertise as good as the parent brand. In this case the advertising has the main role to educate the customer that brand owner also has many of expertise in many of category of products.

To extend the brand, the decision on what category should be involved is very critical to the successful of the brand extension. Brand fit is one of the factors that costumers considered and the other factor is perceived quality of the product. If extension is planned in the right category which mean it is still related to the parent brand, so the perceived quality will leverage this new extension. In this research both two factors have a positive and significant implication to the customer perception on extended brand.

\section{CONCLUSION}

The customer perception on extended brand are affected by its brand fit and perceived quality of its parent brand while the other factors, brand familiarity and customer innovativeness, are not showing their significance.

All of research questions of this study were answered based on the result obtained from data computed, such as Pearson correlation and multiple regression analysis. Result from the hypothesis test indicated that $\mathrm{H}_{3}$ and $\mathrm{H}_{4}$ were rejected and only $\mathrm{H}_{1}$ and $\mathrm{H}_{2}$ were accepted.
Therefore, the final expression model for this regression can be expressed as follow:

Customers Perception on brand Extension $=0.38$ (Brand Fit $)+0.20$ (Perceived Quality) +2.277

Based on equation (3), customer perception on brand extension mostly are influenced by its brand fit to the parent brand and followed by perceived quality of extended brand that relate to its parent brand.

The objective of this research then can be explained using the above equation (3) which determines the degree of the effectiveness of each independent variable on the single dependent variable. The larger coefficient value of the independent variable defined its stronger influence on dependent variable.

In term of significant of study, it is very important for all marketers of brand owner that the successful of extended brand does not rely on the popularity of parent brand and on the assumption that customer will try his or her innovativeness character to use the extended brand. The perceived quality and the relevant extension of the brand to its parent brand more effective to boost the successful of the brand extension.

In the academic environment, this research can be as a trigger to conduct further and a more focus research about the brand extension in other category of products in order to get more understanding what the customer perception about the brand extension.

\section{ACKNOWLEDGEMENTS}

Authors would like to express a great thankfulness to Universiti Teknikal Malaysia Melaka for the opportunity to complete this paper in UTeM and thankfulness also to be addressed the Faculty of Technology Management and Technopreneurship UTeM who always support to the completeness of this research.

\section{REFERENCES}

Aaker, D.A. \& Keller, K.L., 1990. Consumer Evaluations of Brand Extensions. Journal of Marketing, 54(1), pp.27-41. Available at: http://www.jstor.org/ stable/1252171.

Afzal, S., 2013. Factors Influencing Successful Brand Extension into Related and Unrelated Product Categories. Asian Economic and Financial Review, 3(2), pp.216-226. Available at: http://search. proquest.com/openview/1585280b9ccf74562eb5 $83 \mathrm{fec} 34681 \mathrm{f3} / 1$ ?pq-origsite $=$ gscholar.

Arslan, F.M. \& Altuna, O.K., 2010. The effect of brand extensions on product brand image. Journal of Product \& Brand Management, 19(3), pp.170180. Available at: http://www.emeraldinsight.com/ doi/10.1108/10610421011046157.

Beura, D., 2016. FMCG brand extensions strategy 
and consumer buying behavior - An empirical study in Odisha region. International Journal on Recent and Innovation Trends in Computing and Communication, 4(5), pp.443-453. Available at: http://www.ijritcc.org/download/ browse/Volume_4_Issues/May_16_Volume_4

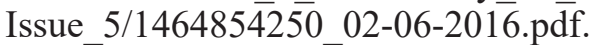

Blomquist, V. \& Holm, R., 2004. Line extensions from a customer's perspective. Luleå University of Technology. Available at: http://epubl.ltu.se/14021773/2004/055/.

Bosinakis, I. \& Johansson, D., 2009. The Effects of Brand Extensions. Luleå University of Technology. Available at: http://epubl.ltu.se/14021773/2009/210/LTU-CUPP-09210-SE.pdf.

Broniarczyk, S.M. \& Alba, J.W., 1994. The Importance of Extension the Brand. Journal of Marketing Research, 31(2), pp.214-228. Available at: http:// www.jstor.org/stable/3152195.

Buil, I., de Chernatony, L. \& Hem, L.E., 2009. Brand extension strategies: perceived fit, brand type, and culture influences. European Journal of Marketing, 43(11/12), pp.1300-1324. Available at: http://www.emeraldinsight.com/ doi/10.1108/03090560910989902.

Çelen, A., Erdoğan, T. \& Taymaz, E., 2005. Fast Moving Consumer Goods: Competitive Conditions and Policies, Ankara, Turkey. Available at: https://ideas. repec.org/p/met/wpaper/0503.html.

Chen, S.J. \& Gu, J., 2012. The Analysis of Challenges and Opportunities in Brand Extension. Halmstad University. Available at: http://www.diva-portal. org $/$ smash/record.jsf?pid=diva2\%3A534912\&ds wid $=4718$.

Coates, S.L., Butler, L.T. \& Berry, D.C., 2006. Implicit memory and consumer choice: the mediating role of brand familiarity. Applied Cognitive Psychology, 20(8), pp.1101-1116. Available at: http://doi.wiley. com/10.1002/acp.1262.

Henry Xie, Y., 2008. Consumer innovativeness and consumer acceptance of brand extensions. Journal of Product \& Brand Management, 17(4), pp.235-243. Available at: http://dx.doi. org/10.1108/10610420810887581.

Keller, K.L., 1993. Conceptualizing, measuring, and managing customer-based brand equity. , 57(1), pp.1-22. Available at: http://www.jstor.org/ stable/1252054.

Keller, K.L., 2016. Reflections on customer-based brand equity: perspectives, progress, and priorities. AMS Review, 6(1-2), pp.1-16. Available at: http://link. springer.com/10.1007/s13162-016-0078-z.

Keller, K.L., 2013. Strategic Brand Management 4th ed. S. Wall et al., eds., London: Pearson Education Limited.

Keller, K.L. \& Aaker, D.A., 1992. The effects of sequential introduction of brand extensions.
Journal of Marketing Research, 29(1), pp.35-50. Available at: http://www.jstor.org/ stable/3172491? origin $=$ crossref.

Khan, K. \& Janthimapornkij, R., 2011. Horizontal Brand Extension and Customer Perception. Karlstad Business School. Available at: http://www.divaportal.org/smash $/$ record.jsf?pid=diva2\%3A4367 $81 \&$ dswid $=4055$.

Kim, C.K., Lavack, A.M. \& Smith, M., 2001. Consumer evaluation of vertical brand extensions and core brands. Journal of Business Research, 52(3), pp.211-222. Available at: http://linkinghub.elsevier. com/retrieve/pii/S0148296399001071.

Klink, R.R. and Smith, D.C., 2001. Threats to the external validity of brand extension research. Journal of marketing research, 38(3), pp.326-335.

Leahy, R., 2011. Relationships in fast moving consumer goods markets: The consumers' perspective. European Journal of Marketing, 45(4), pp.651672. Available at: http://www.emeraldinsight.com/ doi/10.1108/03090561111111370.

Martínez, E. \& Pina, J.M., 2010. Consumer responses to brand extensions: a comprehensive model. European Journal of Marketing, 44(7/8), pp.11821205. Available at: http://www.emeraldinsight.com/ doi/10.1108/03090561011047580.

Martínez, E. \& Pina, J.M., 2003. The negative impact of brand extensions on parent brand image. Journal of Product \& Brand Management, 12(7), pp.432-448. Available at: http://dx.doi. org/10.1108/10610420310506001.

Martinez, E., Polo, Y. \& de Chernatony, L., 2008. Effect of brand extension strategies on brand image. International Marketing Review, 25(1), pp.107137. Available at: http://www.emeraldinsight.com/ doi/10.1108/02651330810851908.

Matarid, N.M., Youssef, M.A.M. \& Alsoud, G.A., 2014. The Impact of Brand Extension Strategy on the Brand Equity of Fast Moving Consumer Goods ( FMCG ) in Egypt. European Journal of Business and Management, 6(21), pp.154-164. Available at: http://citeseerx.ist.psu.edu/viewdoc/download?do $i=10.1 .1 .687 .5015 \&$ rep $=$ rep $1 \&$ type $=$ pdf.

Muhammad, L. \& Ahmad, S., 2011. DOES BRAND EXTENSION IMPACT PARENT BRAND : A CASE OF JOHNSON, UK. Management and Marketing Journal, IX(1), pp.53-66. Available at: http://www.mnmk.ro/documents/2011/5_Pakistan2 FFF.pdf.

Park, C.W., Milberg, S. \& Lawson, R., 1991. Evaluation of Brand Extensions : The Role of Product Feature Similarity and Brand. Journal of Consumer Research, 18(2), pp.185-193. Available at: http:// jcr.oxfordjournals.org/content/18/2/185.

Volckner, F. et al., 2010. The Role of Parent Brand Quality for Service Brand Extension Success. Journal of Service Research, 13(4), pp.379- 
396. Available at: http://jsr.sagepub.com/cgi/ doi/10.1177/1094670510370054.

Williams, A.M., 2015. The Western European Economy
(Routledge Library Editions: Economic Geography): A Geography of Post-war Development (Vol. 11). Routledge.

\section{APPENDIX}

Table 3. Mean Values and Standard Deviations of Brand Extension Dimensions

\begin{tabular}{|c|c|c|}
\hline BRAND EXTENSION DIMENSIONS & Mean & Std.Dev \\
\hline $\begin{array}{l}\text { BRAND FIT (The factor indicate whether there is conceptually fit between parent brand } \\
\text { and extended brand) }\end{array}$ & 5.39 & 1.042 \\
\hline The category of the extended brand is related to the parent brand. & 5.30 & 1.268 \\
\hline The reputation of parent brand can be affected (positively / negatively) by the extended brand. & 5.35 & 1.344 \\
\hline $\begin{array}{l}\text { The product from extended brand should be directed to the customer needs and adapted } \\
\text { to the current situation of the market. }\end{array}$ & 5.54 & 1.169 \\
\hline PERCEIVED QUALITY (The quality of product that customer take into consideration) & 5.73 & 0.924 \\
\hline The product from extended brand should have benefits to users. & 5.94 & 1.006 \\
\hline Product appearance (e.g. package, fragrance) of the extended brand should be more attractive. & 5.52 & 1.173 \\
\hline BRAND FAMILIARITY (Consumer recognition and acquaintance of the brand) & 5.27 & 0.924 \\
\hline The extended brand should be as popular as the parent brand. & 5.02 & 1.264 \\
\hline $\begin{array}{l}\text { Customers should be able to recognize the extended brand by retrieving the experience } \\
\text { from the parent brand. }\end{array}$ & 5.29 & 1.210 \\
\hline The extended brand is easy to memorize and attract the customers. & 5.42 & 1.233 \\
\hline $\begin{array}{l}\text { INNOVATIVENESS (Customer overall judgment of the brand / Customer attitude towards } \\
\text { the extended brand) }\end{array}$ & 5.36 & 1.017 \\
\hline Customers are easier to accept and adapt the innovativeness of the extended brand. & 5.25 & 1.167 \\
\hline $\begin{array}{l}\text { Customers are easy to be attracted and have the interest to purchase the product from } \\
\text { the extended brand. }\end{array}$ & 5.42 & 1.113 \\
\hline Customers are willing to buy the extended product because of its uniqueness. & 5.43 & 1.188 \\
\hline CUSTOMER PERCEPTION DIMENSIONS & Mean & SD \\
\hline CUSTOMER PERCEPTION & 5.96 & 0.852 \\
\hline Customers will provide good perception when they have good experience with the brand. & 5.99 & 0.902 \\
\hline Perception will be good when the customers are satisfied with the extended product. & 6.03 & 0.982 \\
\hline $\begin{array}{l}\text { The extended brand will have a good perception from customers when the company can } \\
\text { deliver the brand promise to the customers. }\end{array}$ & 5.85 & 0.998 \\
\hline
\end{tabular}


Table 4. Pearson Correlation Coefficient

\begin{tabular}{|c|c|c|c|c|c|c|}
\hline & & BRDFIT & PERCQUA & BRDFAM & CUSTINNO & CUSTPERC \\
\hline \multirow[t]{3}{*}{ BRDFIT } & Pearson Correlation & 1 & $.508 * *$ & $.477 * *$ & $.491 * *$ & $.628 * *$ \\
\hline & Sig. (2-tailed) & & .000 & .000 & .000 & .000 \\
\hline & $\mathrm{N}$ & 200 & 200 & 200 & 200 & 200 \\
\hline \multirow[t]{3}{*}{ PERCQUA } & Pearson Correlation & $.508 * *$ & 1 & $.431 * *$ & $.570 * *$ & $.518 * *$ \\
\hline & Sig. (2-tailed) & .000 & & .000 & .000 & .000 \\
\hline & $\mathrm{N}$ & 200 & 200 & 200 & 200 & 200 \\
\hline \multirow[t]{3}{*}{ BRDFAM } & Pearson Correlation & $.477 * *$ & $.431 * *$ & 1 & $.589 * *$ & $.367 * *$ \\
\hline & Sig. (2-tailed) & .000 & .000 & & .000 & .000 \\
\hline & $\mathrm{N}$ & 200 & 200 & 200 & 200 & 200 \\
\hline \multirow[t]{3}{*}{ CUSTINNO } & Pearson Correlation & $.491 * *$ & $.570 * *$ & $.589 * *$ & 1 & $.470 * *$ \\
\hline & Sig. (2-tailed) & .000 & .000 & .000 & & .000 \\
\hline & $\mathrm{N}$ & 200 & 200 & 200 & 200 & 200 \\
\hline \multirow[t]{3}{*}{ CUSTPERC } & Pearson Correlation & $.628 * *$ & $.518 * *$ & $.367 * *$ & $.470 * *$ & 1 \\
\hline & Sig. (2-tailed) & .000 & .000 & .000 & .000 & \\
\hline & $\mathrm{N}$ & 200 & 200 & 200 & 200 & 200 \\
\hline
\end{tabular}

**. Correlation is significant at the 0.01 level (2-tailed).

Table 8. Hypothesis test

\begin{tabular}{|c|c|c|c|c|c|}
\hline Independent Variable & $\begin{array}{c}\text { Margin error } \alpha \\
(95 \% \text { confident interval) }\end{array}$ & Degree of freedom (df) & t-calculated & t-table & Result on Hypothesis \\
\hline Brand Fit & \multirow{4}{*}{0.05} & \multirow{4}{*}{195} & 7.076 & \multirow{4}{*}{1.972} & H1 accepted. \\
\hline Perceive Quality & & & 3.200 & & H2 accepted. \\
\hline Brand Familiarity & & & -0.402 & & H3 rejected. \\
\hline Customer Innovativeness & & & 0.134 & & H4 rejected. \\
\hline
\end{tabular}

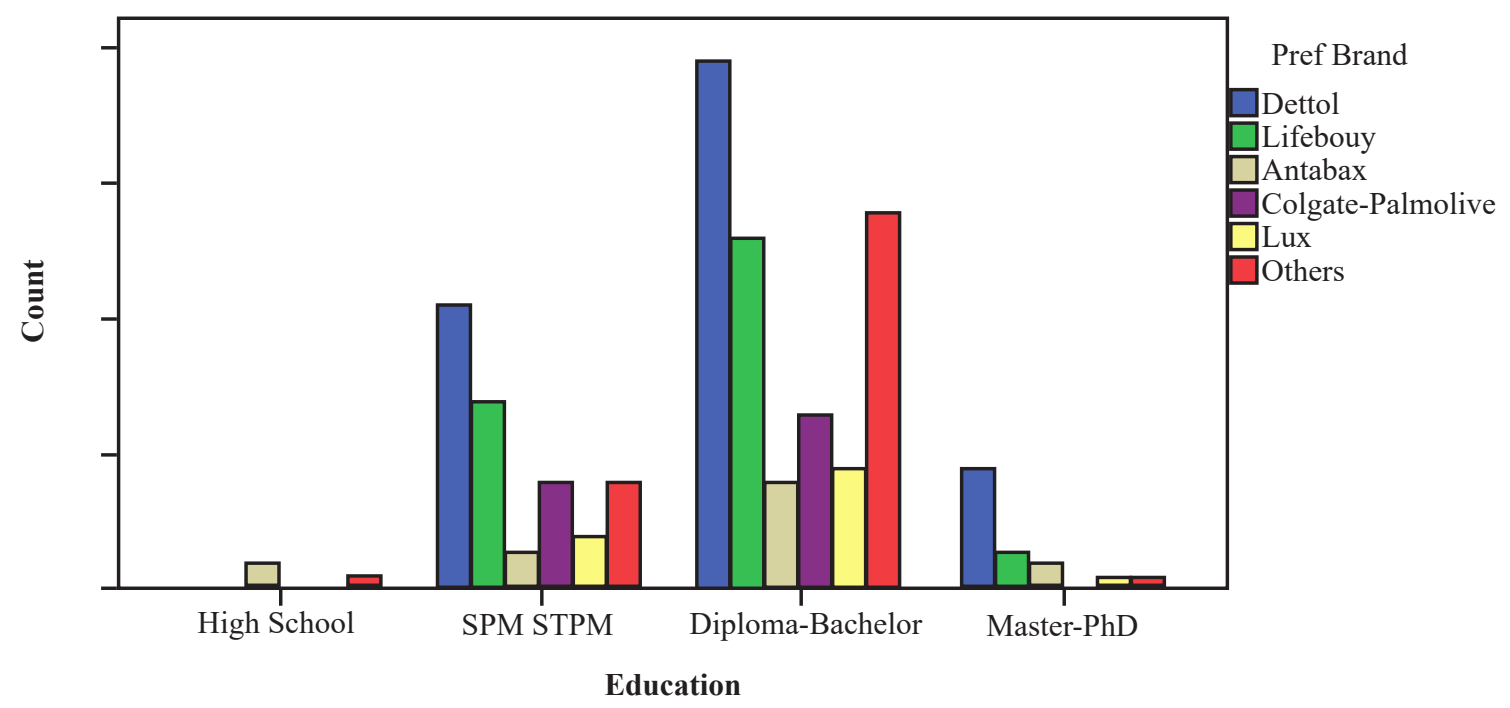

Figure 3. Respondent education vs. preferred brand 


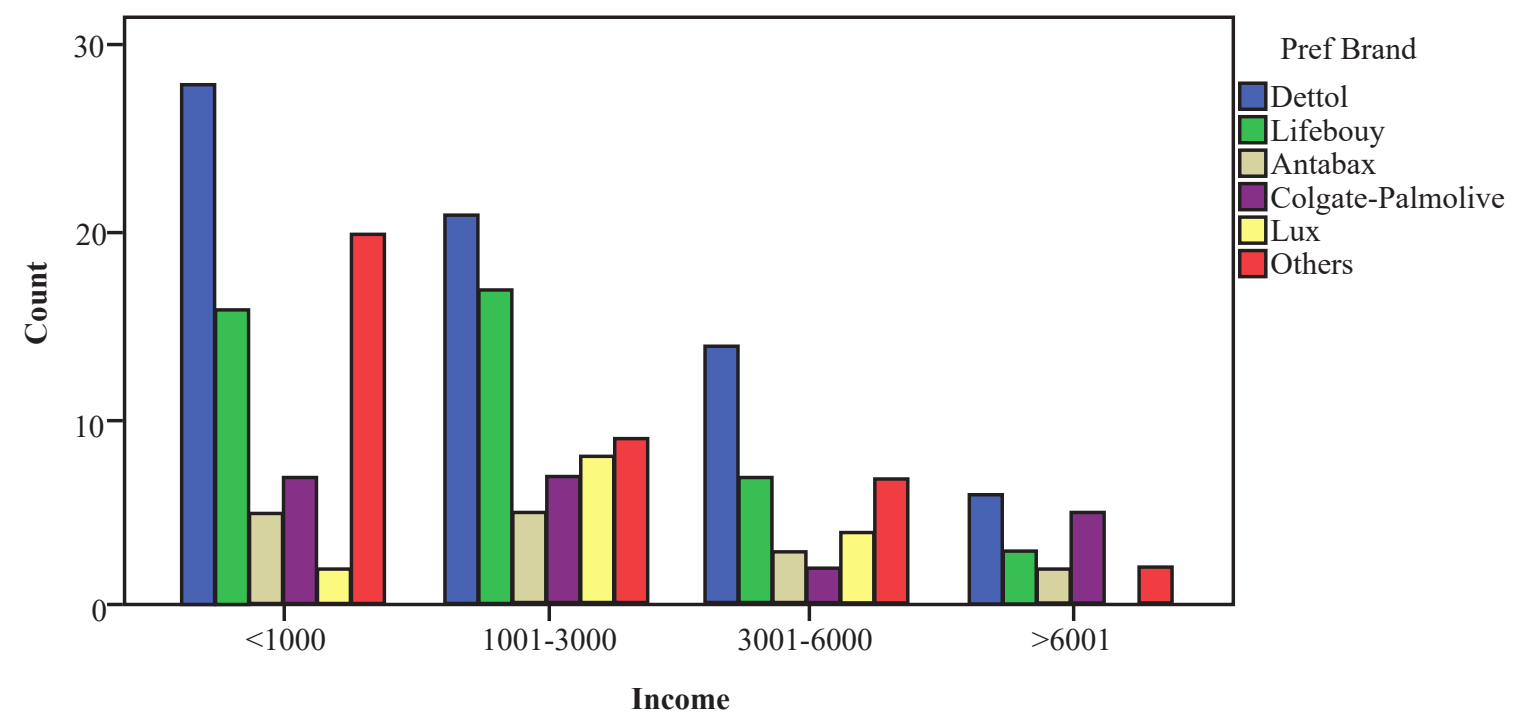

Figure 4. Respondent income vs. preferred brand 